\begin{tabular}{c} 
Volume and Issues Obtainable at Center for Sustainability Research and Consultancy \\
Responsible Education, Learning and Teaching in Emerging Economies \\
ISSN: 2708-4310 \& (E): 2708-4183 \\
Volume 2: No.2, December 2020 \\
CSRᄃ \\
Journal homepage: www.publishing.globalcsrc.org/relate \\
\hline
\end{tabular}

\title{
Comparison of English Writing Skill between Public and Private Sector Schools Students at Secondary Level: In Pakistani Perspective
}

Umm_e_Habiba, Punjab School Education Department, Lahore, Pakistan

*Tahira Batool, Department of STEM Education, Lahore College for Women University, Lahore, Pakistan

Sayeda Ayesha, Punjab School Education Department, Lahore, Pakistan

*Corresponding author's email: tahirashehbaz@yahoo.com

\begin{tabular}{l}
\hline ARTICLE DETAILS \\
\hline History \\
Revised format: Nov 2020 \\
Available Online: Dec 2020
\end{tabular}

\section{Keywords}

Creative writing skill,

Use of grammar,

Translation into English.

JEL Classification

I20, A21

\section{ABSTRACT}

Purpose: The objective of the study was to compare the English writing skills of English in the classroom at secondary level. Design/Methodology/Approach: The study was carried on sample of hundred students of secondary level drawn from simple randomly selected from five private and five public secondary schools of Lahore. Self-structured test was used to compare English writing skill at secondary level. There were two sections of test, essay type and translation of ten sentences into English. The data collected was analyzed by using percentage and results obtained were converted to descriptive findings.

Findings: The result showed English writing skill of private school students is better than public schools students because majority of the private school students have correct sentence structure, Subject verb agreement in essay writing, correct Translations of Urdu sentences into English as compared to the public school students. In addition, most of the public schools student's spelling, use of tenses and uses of auxiliaries are good and correct in essay writing rather than the private school students.

Implications/Originality/Value: So it is concluded that exercises for the English writing skill may be maximized in both public and private schools by using various teaching techniques.

(C) 2021 The authors, under a Creative Commons Attribution-

\section{OPEN ACCESS} NonCommercial 4.0

\footnotetext{
Recommended citation: Habiba, U., Batool, T. and Ayesha, S. (2020). Comparison of English Writing Skill between Public and Private Sector Schools Students at Secondary Level: In Pakistani Perspective. Journal of Business and Social Review in Emerging Economies, 2 (2), 75 84.
}

\section{Introduction}

Language is the vehicle for effective communication. Every student needs to develop the skills such as listening, speaking, reading, and writing because these are the source which enable to 
communicate properly in the society (Philomina, 2015). Writing is a creative and active process of the mind by which the writer creates meaningful message (Philomina, 2015). Furthermore, for inculcating education English is a vital subject in curriculum (Singapore's Ministry of Education, 2010)

Creative writing has a important place in the educational institutions (Chandio, Khan \& Samiullah, 2013). Moreover, Students require effective English writing skill is for their academic success and personal development (Mukulu, Indangasi, Mwangi, Gecaga \& Okanga 2006).Similarly, Rao (2007) pointed out that writing is playing important role to build up students' learning, thinking and reflecting on the English language in their academics. In addition, Finding of Ahmed's (2010) study proved that those students who are competent in writing help them to perform well in their academic programs.

Rahman (2007) argued that secondary school students has high rate of failure in English writing skill because writing skill was not developed properly. In addition, they have no idea of creative writing. In the same way, content analysis of the essay English writing skills showed that serious problems in spelling, simple present tense, using appropriate forms of adjectives, recognizing passive voice, punctuation marks and using relative pronouns and prepositions were facing by the university students in Tanzania (Njabili, Kafanabo, Komba, Komba, \& Kira, 2012). Furthermore, Muhammad, Masum, Ali, and Baksh (2017) revealed that teacher-centered teaching approach did not provide the opportunity of developing language skills to the students through practice in classrooms. Correspondingly, students need to be successful in workstation, school, and their personal lives but mostly students fail to develop the competence of creative writing (Graham and Perin, 2007).

\section{Pakistani Perspective}

Secondary schools students of Pakistan do not write creative essay because they are habitual of rote learning in essays and stories. Next, they also like Grammar Translation Method. Furthermore, they avoid to communicate in English (Awan \& Shafi, 2016). In the same way, it has been observed by Rahman (2002) that the most of the secondary school students rely on cramming and has lack of ability of writing creatively in Pakistan. In addition, Pakistani secondary school students need of expertise in creative writing skills for a number of educational purposes for example writing tasks and assignments given by the teachers and final examinations etc. (Dar \& Khan, 2015). In Pakistan a majority of people has accepted the importance of English language. But some people who are prejudiced and biased are against teaching of English to the new generation.

\section{Literature Review}

Msanjila (2005) stated that writing is skilled behavior performed in order to convey or record information or thoughts. Writer may wish to convey a message to someone else, or he may wish to keep a record of some event or thought for future reference.

\section{Categories of Writing Problems}

Msanjila (2005) stated about the categories of writing problems: capitalization problem, punctuation problem, inexplicitness/fuzziness, poor organization / illogical sequence, spelling problem, and grammatical errors

\section{Factors Affect English Writing Skill in the Classroom}

It was reported that overcrowded classrooms, teachers' workload, poor infrastructure, examination system and inefficient monitoring mechanism are influencing factors on the English writing skill of students (Muhammad, Masum, Ali, \& Baksh, 2017). Similarly, researchers proved that writing skill of students (creativity, ideas and command over grammar and 
vocabulary) is unsatisfactory because teachers did not involve students in English writing practice (Emmitt, Zbarackiet, Komesaroff \& Pollock, 2003).

Moreover, it is essential to revise the English text book at secondary level. In addition, in order to involve the students in learning there is need a book with language activities. Furthermore, all the four language skills should be covered in book (Sahu, 2004). Thus, existing teaching methods used by the teachers are not satisfactory for developing the language skills of students, (Nawab, 2012). Findings of Okwaras' (2012) study showed that inadequate evaluation may easily affect writing competence of secondary level students. Another similar study was conducted by Farooq (2012) indicated that second language learners faced a lot of difficulties in English writing skill because they have lack of vocabulary, poor spelling, L1 interference and poor understanding of grammatical structures. A study carried out by Msanjila (2005) shed light on those writing problems which faced by the secondary school students in Tanzania, such as, capitalization and punctuation errors, inexplicitness or fuzziness, poor organization of sentence making or illogical sequence, spelling and grammatical mistakes.

The finding of the study showed that most of the students faced some problems to develop English language skill in Tanzania (Komba \& John, 2015). Parallel to findings of previous studies, Mohite (2014) proved the lack of understanding in the compositional aspect of the English writing.

\section{Strategies to Improve the English Writing Skill}

Therefore, the implications of the Mohites (2014) suggested in the light of his study that there is need to raise learners' awareness about English writing compositional skills and highlight the communicative purpose of writing in English. Finally, train the students train to use the peer collaboration strategy to facilitate their English writing most effectively. In addition, it was recommended by Komba \& John (2015), recruit those teachers who are proficient in English language at primary level, then they will able to become role model for learners. Another study was suggested; provide adequate practice of essay writing to the students by the teachers (Okwara, 2012). In the light of findings of previous studies, it was recommended by Yigzaw (2013) that 11 grade Ethiopian students need to pay attention on grammar and vocabulary teaching approach because it would enable them to apply in their English writing skill. In conclusion, Moore (2014) and Lloyd, Blaus \& Sousa (2017) presented another point of view that develops English writing skill through enhancing extensive reading. In addition, the findings of Msanjilas'(2005) study showed, students' writing problems arise from pedagogical reasons in secondary school of Tanzania. But, professional language teachers can minimized students' writing problems. Similarly, In Nigeria, Ayodele, Akinkurolere, Ariyo, Mahmud, and Abuya (2017) shed light on cooperative writing strategy which is one of the innovative ways to improve students' learning and performance because it involves role-playing and role-shifting.

A great significance of this survey is to find out the difference between the English writing skill of public and private school students at secondary level. This survey has its special worth for teachers and institutions to make English writing skill affective for students. This study will also be useful for teachers of public and private schools to take advantages to improve the deficiencies of English writing skill. This research will guide the teachers of secondary schools to give importance to the English writing skill along with other skills. This research study will also compare the English writing skills of students of public or private school.

\section{Objectives of the Study}

Objectives of the study are:

- $\quad$ To investigate the difference between English writing skill of public and private schools students at secondary level. 


\section{Hypothesis}

Hypothesis of the study were:

Ho1 There is no significant difference in students' English writing skill of public and private Secondary schools

Ho1.1 There is no significance difference in the essay type test means scores of public and private sector schools students.

Ho1.2 There is no significance difference in the translation into English test means scores of public and private sector schools students.

\section{Delimitation of Study}

This study was delimited to the ten secondary schools (Five public and five private) of Lahore district, Tehsil Cantt.

\section{Methodology}

Following procedure was adopted in collecting, analyzing and interpreting data for the research work.

\section{Nature of Research}

Research was descriptive and quantitative in nature.

\section{Method of Research}

The researcher used survey method in this research work.

\section{Population}

The population of this research was secondary students of public and private schools of Lahore city.

\section{Sample and Sampling Technique}

Hundred students from five public and five from private sector schools.

- 10 schools of Lahore district (Tehsil Cantt.) were selected for this study by using simple random sampling, in which five public and five private schools were included.

- Simple random sampling technique was used for selecting the 50 students of $10^{\text {th }}$ grade from private and public secondary schools.

\section{Tools of Research}

A writing skill test was essay type (open ended) and other was translation into English (close ended).

\section{Rationale}

As the writing ability of students is judged through a criteria that is product based, that's why a test was developed consisting of an open ended (essay type) and a close ended (translation into English) question. First part was developed to check creative writing of students and second part was developed to check the grammatical competence of students. Translation into English was chosen for two reasons firstly because the paper pattern of English at secondary level includes a question based on translation into English or translation into Urdu. Secondly GMT (Grammer translation methods) is used in most of the schools to teach English.

\section{Data Collection Procedure}

The test was conducted for 30 minutes. The students were not informed prior that they have to appear in the test. The test was administered and conducted by the researcher. 


\section{Analysis of Data}

The research supervised all scoring of answer sheet herself. The collected data was analyzed and interpreted in order to get factual results. The researcher used percentage method to analyzed data. The data is presented in the form of tables.

Data is analyzed by comparing the writing of students of both schools. Analysis consisted on the two sections, first section deals with the analysis of creative writing skill of public and private school students separately on creative writing, second is consisted on the analysis of grammatical competence of the students of both the schools separately and third section is consisted on the comparison of English writing skill of public and private secondary schools. The writing skill of the students in checked on the basis of errors they make. As the population of this study is the students of secondary level and at secondary level in Pakistan a student is required to produce fundamental sentences. So following few errors are analyzed in the writing of the students.

- Tense

- Spelling

- Subject-verb agreement

- Use of auxiliaries/helping verbs

- Sentence-structure

After taking the data, percentage method wad used by multiplying the total number of errors of each item by hundred and dividing these by the total number of students.

Following formula was used for analysis of writing skill:

Total number of errors of each item $\quad * 100$

Total number of students

(Each type of error is counted only even if occurs multiple times).

Table No1: Comparison of Top Five Errors in Written Composition of the Students of Public and private Schools

\begin{tabular}{llllll}
\hline & & \multicolumn{2}{l}{ Public School Students } & \multicolumn{2}{l}{ Private School Students } \\
Sr. No. & Statement & $\begin{array}{l}\text { Errors } \\
\text { Errors }\end{array}$ & $\boldsymbol{\%}$ \\
\hline 1. & & $\boldsymbol{F}$ & $\boldsymbol{\%}$ & $\boldsymbol{f}$ & 12 \\
2. & Tense & 8 & 16 & 6 & 50 \\
3. & Spelling & 19 & 38 & 25 & 30 \\
4. & Subject verb agreement & 4 & 8 & 15 & 12 \\
5. & Use of auxiliaries & 18 & 36 & 6 & 34 \\
\hline
\end{tabular}

\section{Analysis of Table No.1 indicates}

- Tense errors of public school students are $16 \%$ and $12 \%$ are of private school students.

- Spelling mistakes of public school students are 38\% and 50\% of private school students.

- $8 \%$ errors of subject verb agreement are of public school students and $30 \%$ are of private school students.

- Errors of use of auxiliaries are $36 \%$ of public school and $12 \%$ of private school students.

- $62 \%$ sentence structures of public school students are wrong and $34 \%$ are of private school students.

Table No.2: Comparison of 1 to 5 translate sentences of public and private school students

\begin{tabular}{|c|c|c|c|c|c|c|c|c|c|}
\hline \multirow{3}{*}{ Sr. No. } & \multirow{3}{*}{ Statement } & \multicolumn{4}{|c|}{ Public School Students } & \multicolumn{4}{|c|}{ Private School Students } \\
\hline & & \multicolumn{2}{|c|}{ Correct } & \multicolumn{2}{|c|}{ Incorrect } & \multicolumn{2}{|c|}{ Correct } & \multicolumn{2}{|c|}{ Incorrect } \\
\hline & & $f$ & $\%$ & $f$ & $\%$ & $f$ & $\%$ & $f$ & $\%$ \\
\hline 1. & & 18 & 36 & 32 & 64 & 30 & 60 & 20 & 40 \\
\hline 2. & & 10 & 20 & 40 & 80 & 17 & 34 & 33 & 99 \\
\hline
\end{tabular}


3.

4.
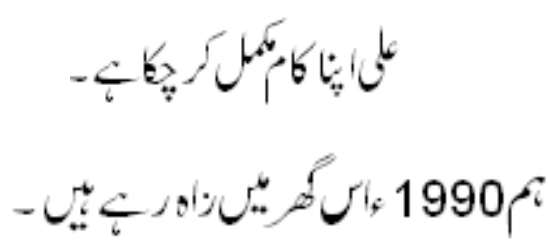

5.

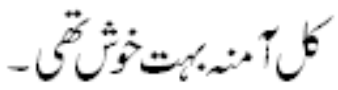

2

42

29

58

28

36

22

44

$18 \quad 36 \quad 32$

64

24

$48 \quad 26$

52

32
64

36

$\begin{array}{lll}80 & 10 & 20\end{array}$

40

\section{Analysis of Table No.2 indicates}

- Item one indicates that $36 \%$ sentences are correct of public schools and $60 \%$ of private schools.

- Item two indicates that $20 \%$ sentences are correct of public schools and $34 \%$ of private schools.

- Item three indicates that $42 \%$ sentences are correct of public schools and $36 \%$ of private schools.

- Item four indicates that $36 \%$ sentences are correct of public schools and $48 \%$ of private schools.

- Item five indicates that $64 \%$ sentences are correct of public schools and $80 \%$ of private schools

Table No.3: Comparison of 6 to 10 translate sentences of public and private school students

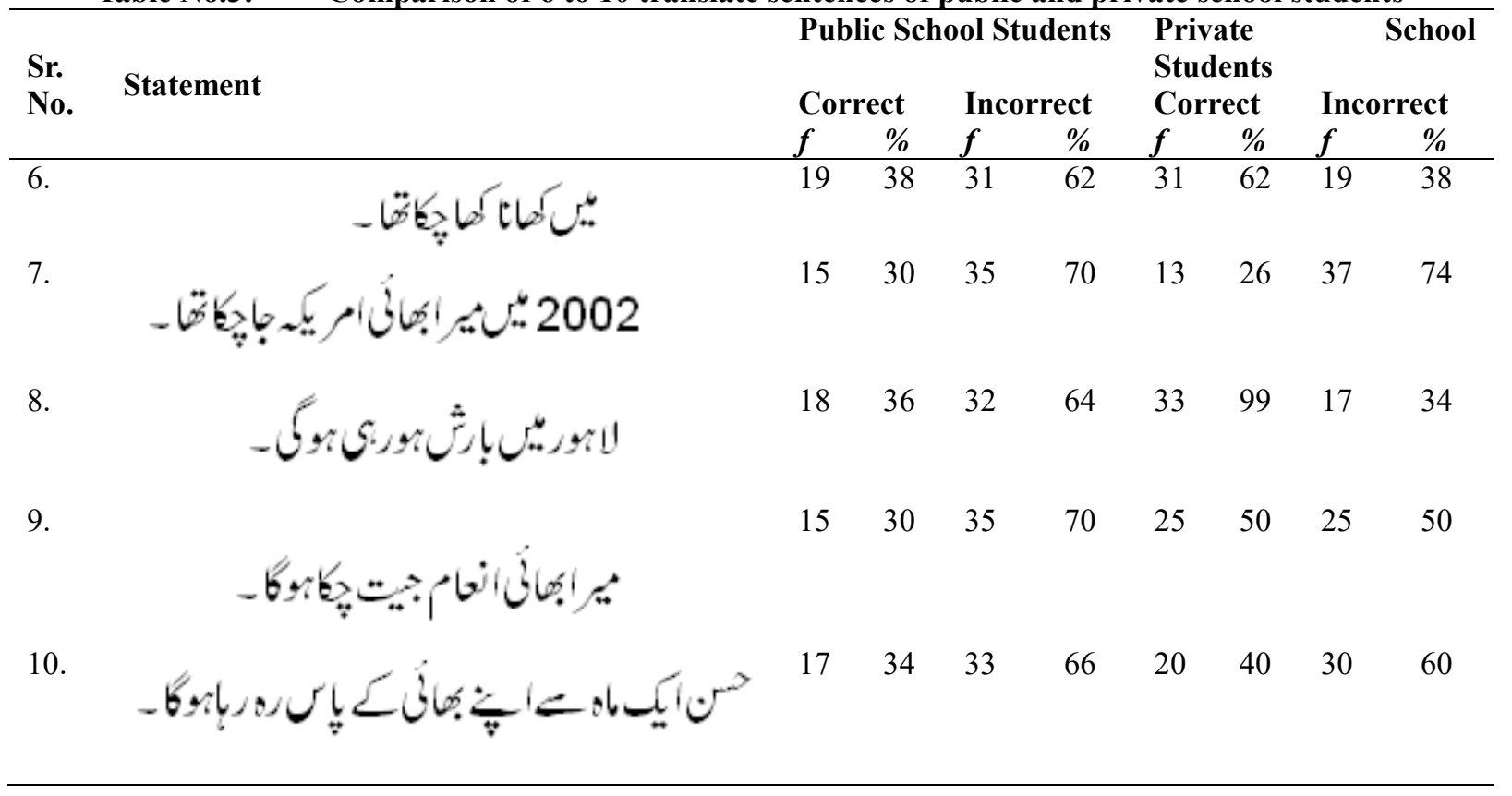

\section{Analysis of Table No.3 indicates}

- Item six indicates that $38 \%$ answers of public school students and $62 \%$ of private school students are correct.

- Item seven indicates that $14 \%$ answers of public school students and $26 \%$ of private school students are correct.

- Item eight indicates that $36 \%$ answers of public school students and $99 \%$ of private school students are correct.

- Item nine indicates that $30 \%$ answers of public school students and $50 \%$ of private school students are correct.

Item ten indicates that $34 \%$ answers of public school students and $40 \%$ of private school students are correct. 


\section{Conclusion and Discussion}

After the analysis of data, findings were drawn \& in the light of findings, it was concluded that: This study was proposed to investigate the difference between English writing skill of public and private schools students at secondary level. The results of the current study demonstrated that English writing skill of private school students is better as compared to the studnets of public school because majority of the private school students have correct sentence structure, Subject verb agreement in essay writing as compared to the public school students. This supports the points of view that creative writing skills among the secondary school students are dissatisfactory as compared to private sector school students in Bahawalpur (Chandio, Khan \& Samiullah, 2013; Rahman, 2002; Siddiqui, 2007; Bashiruddin, 2009; Rahman, 2007). Similarly, Arifa (2009), and Shah, Rani, Mehmood and Irum (2013) proved that secondary school students choose specific educational material, memorize it and try to write in exams in Pakistan because they are not able in writing themselves. In line with previous studies, brainstorming, group work and presentation for generating ideas regarding developing writing skills are used in classrooms by $\mathrm{O}$ level teachers as compared to teachers of secondary schools in Pakistan (Fatima \& Akbar, 2017). Correspondingly, lack of pre-writing activities, poor in vocabulary, grammar, punctuation and spellings, lengthy syllabus and limited time are main issues in Pakistani secondary schools which are facing by students while they write (Fareed, Jawed, \& Awan, 2018). In the same way, Naeem (2011) found in his study that O level students are good in creative English writing skill as compared to secondary school student in Pakistan. In addition, findings of many researches also showed that students had difficulties in English writing such as grammar (spelling, punctuation), vocabulary, content and organization of the sentences in Kenya and Pakistan (Hussain, 2013; Njabili, Kafanabo, Komba, Komba, \& Kira, 2012; Farooqi, 2014; Nyasimi, 2014).

Another finding of this study is, most of the public schools student's spelling, use of tenses and uses of auxiliaries are good and correct in essay writing rather than the private school students. In addition, Hassan, Rehman and Masum (2015) stated, English writing skill of Bangladeshi students is satisfactory, but overall they made errors (Punctuation, capitalization). Likewise, findings of study pointed out the significant difference between government, aided and private Primary school students regarding reading and writing skills in U.K. (Philomina, 2015). In the same way, the essays of Swedish students are better in writing quality and they got higher scores but they were lacking in spelling (Villanueva, 2008).

One of the most important results reported by this study is that majority of private school students have correct Translations of Urdu sentences into English as compared to public school students. Likewise, Ali, Ahmad, Manzoor, and Naseer (2014); Aqeel and Sajid, (2014) also argued that the students of secondary school are facing many problems in learning of three forms of verb, narration, reading comprehension, sentence arrangements, parts of speech (conjunctions, prepositions) and articles. Moreover, teacher related problems were also identified such as teachers did not focus on writing skill, lack of constructive feedback and had not did correction of spelling and grammar (Aqeel \& Sajid, 2014; Khan, 2011)

In Nutshell, we can say that there is less number of students of public school who respond correctly rather than to private school students. So, private school students are better in English writing skill as compare to public students. But errors are equally done in the essay question by public and private sector students.

\section{Recommendations}

- There is need to improve English writing skills of public schools students by using various teaching methods.

- Public school Teachers need to improve the sentence structure of students through practice of sentence making. 
- Public school students need to improve their creative writing skill without doing spelling mistakes, the errors of tenses, using of helping verbs and subject verb agreement.

- If teachers encourage students in English writing skill, students can get success in correcting grammar errors.

\section{References}

Ahmed, A. (2010).Students' problems with cohesion and coherence in EFL essay writing in Egypt: Different perspectives. Literacy Information and Computer Education Journal (LICEJ), 9(1), 219-221

Ayodele, V., Akinkurolere, S., Ariyo, K., Mahmud, O., \& Abuya, E. (2017). The Teaching of Essays, Articles and Letter Writing: Cooperative Teaching Approach. Asian Research Journal of Arts \& Social Sciences, 4(2), 1-7. doi: 10.9734/ARJA SS/ 2017/35161

Arifa, R. (2009). College teachers 'perceptions of ELT: Relevance to teacher training, in Mansoor, S, Sikandar, A, Hussain, N, \& Ahsan N. M. (eds.) Emerging Issues in TEFL Challenges for Asia, Oxford: Oxford University Press.

Ali, S., Ahmad, N., Manzoor, N., \& Naseer, S. (2014). Students' Perceptions about Teaching English as Compulsory Subject at Secondary Level in Punjab, Pakistan. Bulletin of Business and Economics (BBE), 3(1), 21-33.

Aqeel, R. M., \& Sajid, M. A. (2014). A study of organizational problems faced by Pakistani student writers. International Journal of Science and Research, 3(11), 258-261

Awan, G. A., \& Shafi, M. (2016). Analysis of teaching methods of English language at government secondary school level in D.G. khan city Pakistan. Global Journal of Management and Social Sciences, 2(2), 29-46.

Bashiruddin, A. (2009). Learning English and learning to teach English: The case of two teachers in Pakistan, in Mansoor, S, Sikandar, A, Hussain, N, \& Ahsan N. M. (eds.) Emerging Issues in TEFL Challenges for Asia, Oxford: Oxford University Press

Bowen, J. D., Madsen, H., \& Hilforty, A. (1985). TESOL techniques \& procedures learning. Cambridge: Newbury House Publisher.

Himdambaram, K. (2005, December). A study on the process of English by higher secondary students. Retrieved December, 2005, from http://www.languageinindia. com/dec2005/chi mdambaramthesis1.html

Chandio, H. J., Khan, A. M. H., \& Samiullah, M. (2013). Condition of Creative Writing in the North and South Punjab. Pakistan Journal of Commerce and Social Sciences, 7(2), 321330.

Dar, M. F., \& Khan, I. (2015). Writing Anxiety among Public and Private Sectors Pakistani Undergraduate University Students. Pakistan Journal of Gender Studies, 10(5), 157-172

Emmitt, M., Zbarackiet, M., Komesaroff, L., \& Pollock, J. (2003). Language and learning: An introduction for teaching. ( $3^{\text {rd }}$ ed). Oxford. University Press: New York

Farooq, M. (2012). Opinion of second language learners about writing difficulties in English language. A research Journal of South Asian Studies, 27(1), 183-194

Fareed, M., Jawad, S., \& Awan, S. (2018). Teaching English Language at SSC Level in Private Non-Elite Schools in Pakistan: Practices and Problems. Journal of Education and Educational Development, 5(1), 80-95.

Fatima, Q., \& Akbar, A. R. (2017). Comparison of Teaching Practices in English Writing Classrooms of Secondary School Certificate and General Certificate of Education Ordinary Level. Journal of Educational Research, Dept. of Education, 20(2), 15-27.

Graham, S., \& Perin, D. (2007).A Meta-analysis of writing instruction for adolescent students. Journal of education research, Vol. 99,445-476

Hassan, I. M., Rehman, M., \& Masum, A. A. (2015). An Analysis and Evaluation of English Writing Skills of Class Five Students at Government Primary Schools in Dhaka City. International Journal of Science and Research, 5(4), 921-927. Retrieved from, www.ijsr.net 
Hussain, A. (2013). A process approach in improving grade VIII students' writing skills in a government school of District Kech Turbat. (Unpublished master's dissertation). Aga Khan University, Karachi, Pakistan

Khan, H. I. (2011). Testing creative writing in Pakistan: Tensions and potential in classroom practice. International Journal of Humanities and Social Sciences, 1(15), 111-119.

Komba, C. S., \& John, D. (2015). Investigation of Pupils' English Language Abilities in Tanzania: The Case of English Medium Primary Schools. World Journal of English Language, 5(1), 56-64. doi:10.5430/wjel.v5n1p56

Lloyd, J., Blaus, E., \& Sousa, H. (2017). An investigation of Portuguese students' attitudes to assessment and Cambridge English exams. Research Notes, issue 65(7), 24-38.

Moore, N., Knight, G. \& Kiburz. (2014). Developing an assessed reading portfolio to improve reading habits and raise test result. Retrieved fro http://shura.shu.ac. uk/9780/1/Moore-Knight-Kibburz-inEmery-Moo TLRReadingin ELTTESOL Ar14.pdf

Mohite, M. (2014). An Investigation into the English Language Writing Strategies Used by Polish EFL Secondary School Learners. Unpublished master's thesis. London Metropolitan University

Msanjila, P. Y. (2005). Problems of Writing in Kiswahili: A Case Study of Kigurunyembe and Morogoro Secondary Schools in Tanzania. Nordic Journal of African Studies, 14(1), 15-25

Muhammad, N., Masum, R., Ali, Z., \& Baksh, K. (2017). Teaching Practices of English Language in Te Schools of Lasbela District, Pakistan. International Journal of Experiential Learning \& Case Studies, 2(2), 34-39. Retrieved from, www.journals.iobmresearch.com/index.php/JELCS/article/download/1942/349

Mukulu, E., Indangasi, H., Mwangi, P., Gecaga, C. \& Okanga, N. (2006.) KCSE revision English. Nairobi.Kenya Literature Bureau.

Naeem, M. I. (2011). A comparative study of secondary school certificate (SSC) and General Certificate of Education-Ordinary level (GCE-O level) English language course. (Unpublished doctoral dissertation). International Islamic University, Islamabad, Pakistan

Nawab, A. (2012). Is it the way to teach language the way we teach language? English language teaching in rural Pakistan. Research International, 2(2), 696-705. Retrieved from, htp://ecommons.aku.edu/pakistan_ied_pdcc/9

Njabili, F. A., Kafanabo, J. E., Komba, C. S., \& Kira, S. E. (2012). Comparison between students' academic performance and their abilities in written English language skills: A Tanzanian perspective. International Journal of Development and Sustainability, 1(2), 305-325. Retrieved from, www.isdsnet.com/ijds

Nyasimi, B. N. (2014). Challenges students face in learning essay writing skills in English language in secondary schools in manga district, nyamira county, Kenya. Unpublished masters thesis. School of Education Kenyatta University

Okwara, M. O. (2012). A study of factors related to achievement in written composition among secondary school students in Busia district. Unpublished masters thesis. Kenyatta University

Philomina, M. J. (2015). Diagnosis of reading and writing skills in primary school Students. International Journal of English Language Teaching, 3(7), 1-7. Retrieved from, www.eajournals.org.

Rahman, T. (2002). Language, ideology, and power: Language learning among the Muslims of Pakistan and North India, Oxford: Oxford University Press.

Rahman, T. (2007). Denizens of alien worlds a study of education, inequality, and polarization in Pakistan, Oxford: Oxford University Press

Rao.Z. (2007). Training in brainstorming and developing writing skills. ETL Journal, 61(2), 44-51.

Shah, K. S., Rani, R., Mehmood, R., \& Irm, R. (2013). An investigation of critical thinking 
levels of examination questions for B.A. compulsory English at university of Punjab. International Journal of Linguistics, 5(2), 252-261.

Sahu, B. K. (2004). Principals of teaching English.Kalyani Publishers: New Delhi. Siddiqui, S. (2007). Rethinking education in Pakistan: Perceptions, practices, and possibilities, Karachi: Paramount Publishing Enterprise.

Singapore's Ministry of Education. (2010). English language syllabus 2010: Primary \& secondary. Retrieved from http://www.moe.gov.sg/education /syllabuses /englishlanguagandliterature/files/english-primary-secondary-express-normal-academic.pdf

Villanueva, A. (2008). An international comparative study on English writing proficiency in two secondary school settings. Essay. University of Gavle. Retrieved from, http://www.div portal.org/smash/record.jsf?pid =diva2\%3 A211250\&dswid=5793

Yigzaw, A. (2013). Students' first language writing skills and their English language proficiency as predictors of their English language writing performance. Academic Journals, 4(6), 109-114. Retrieved from, http://www. Academic journals.org/JLC 